\title{
MyD88-adaptor protein acts as a preventive mechanism for memory deficits in a mouse model of Alzheimer's disease
}

\author{
Jean-Philippe Michaud, Karine L Richard, Serge Rivest ${ }^{*}$
}

\begin{abstract}
Background: Alzheimer's disease (AD) is an age-related neurodegenerative disorder associated with brain innate immune activation mainly mediated by microglia. These cells are known to be activated in the brain of AD patients and to produce inflammatory cytokines and neurotoxic molecules in response to Amyloid beta (AB). Activation of microglia can also promote $A \beta$ clearance via Toll-like receptors (TLRs). Myeloid differentiation factor 88 (MyD88) is the adaptor molecule for most of these innate immune receptors, transducing the intracellular signal from TLRs to nucleus.

Results: Here, we report that more than 50\% reduction in MyD88 expression in a mouse model of AD accelerated spatial learning and memory deficits. Brain of $\mathrm{APP}_{\text {swe }} / \mathrm{PS} 1-\mathrm{MyD} 88^{+-}$mice was characterized by a delay in accumulation of $A \beta$ plaques and increased soluble levels of $A \beta$ oligomers. Furthermore, inflammatory monocyte subset and brain IL-1 $\beta$ gene expression were significantly reduced in APP swe/PS1 mice with impaired MyD88 signaling.

Conclusions: These data indicate that activation of MyD88 intracellular signaling pathway, likely by TLRs, acts as a natural innate immune mechanism to restrict disease progression of $\mathrm{APP}_{\text {swe }} / \mathrm{PS1}$ mice.
\end{abstract}

\section{Introduction}

Alzheimer's disease (AD) is the most common neurodegenerative pathology related to aging that results in progressive neuronal death and memory loss. Neuropathologically, this disease is characterized by the presence of both neurofibrillary tangles and plaques composed of aggregates of amyloid- $\beta$ (A $\beta$ ) protein, a proteolytic fragment derived from the amyloid precursor protein (APP). As described by the amyloid cascade hypothesis, AD pathogenesis is associated with alterations in $A \beta$ homeostasis resulting in an accumulation of $A \beta$ peptides within the brain parenchyma that may exert neurotoxic effects and neuronal death [1]. Historically, amyloid plaques were correlated with cognitive deficits. Accumulating evidences suggest that soluble, oligomeric and even intracellular, rather than

\footnotetext{
* Correspondence: Serge.rivest@crchul.ulaval.ca Laboratory of Endocrinology and Genomics, CHUL Research Center and Department of Molecular Medicine, Faculty of Medicine, Laval University, 2705 Laurier boul., Québec, G1V 4G2, Canada
}

insoluble deposits of $A \beta$, correlate more strongly with dementia severity [2].

Inflammation is an important pathological component in the brains of AD patients. As proposed by the inflammation hypothesis of $\mathrm{AD}$, the neurodegenerative process could be exacerbated by a chronic inflammatory response to $A \beta$ peptides. Fibrillar $A \beta$ deposits in $A D$ brains are accompanied by innate immune responses such as activated microglia and increased levels of cytokines [1]. Microglia are the brain's tissue macrophages and the primary immune effectors within the CNS that respond to many pathological events. They are highly dynamic and respond rapidly to perturbations within the brain $[3,4]$. Accumulating evidence supports the hypothesis that microglia responses play a pivotal role in the pathogenesis of AD; however, their exact roles have not been yet resolved. Microglial activation is associated with production of neurotoxic mediators and inflammatory cytokines that can lead to neuronal death and may contribute to chronic neurodegenerative conditions [5]. On the other hand, microglia can phagocyte $A \beta$, produce $A \beta$ degrading

\section{Biomed Central}


enzymes and then be neuroprotective by clearing $A \beta$ from the brain [6]. The molecular mechanisms by which the innate immune system modulates the progression of $\mathrm{AD}$ are not well understood. A better understanding of the processes that regulate microglial activation may enhance the possibility of finding therapeutic approach against $\mathrm{AD}$.

Toll-like receptors are transmembrane pattern recognition receptors that act as sensor for specific elements termed as pathogen-associated molecular pattern (PAMPs). These receptors are involved in innate immunity and inflammatory response by triggering activation of immune cells. To date, 10 different functional TLRs have been identified in humans and 12 in mice [7]. They display distinct ligand specificities and they are known to bind many endogenous proteins [8]. Recent work has implicated these receptors in microglial recognition and response to $A \beta$. Plaques associated-microglia exhibit elevated TLR2, TLR4, TLR5, TLR7 and TLR9 mRNA levels [9]. Stimulation of microglia with innate immune ligands for TLR2, TLR4 and TLR9 was found to accelerate $A \beta$ clearance in vitro and in mouse model of AD $[10,11]$. Mutations in TLRs, such as TLR4, are risk factors for $\mathrm{AD}[12]$. $\mathrm{A} \beta$ can also directly bind TLR2 and TLR4 [13].

Taken together these studies argue for the involvement of innate immune system and TLRs in the course of $\mathrm{AD}$, although the exact mechanisms mediating these effects have yet to be uncovered. MyD88 bridges most TLRs to the downstream signaling elements mitogenactivated protein kinases (MAPKs) and nuclear factorkappaB (NF- $\kappa \mathrm{B})$, which trigger transcriptional activation of inflammatory genes [8]. MyD88 is also essential for triggering expression of innate immune genes in microglia following exposure to both exogenous and endogenous toxic stimuli $[14,15]$. The aim of the present study was therefore to determine the role of MyD88 in the pathogenesis of $\mathrm{AD}$. We thus generated a mouse model of AD in a context of MyD88 deficiency. Our data from these mice suggest a critical neuroprotective role of the MyD88 pathway in $\mathrm{APP}_{\text {swe }} / \mathrm{PS} 1$ mice.

\section{Materials and methods}

Transgenic mouse lines

$\mathrm{APP}_{\text {swe }} / \mathrm{PS} 1$ transgenic mice harbouring the human presenilin I (A246E variant) and the chimeric mouse/human A $\beta$ precursor protein (APP695 swe) under the control of independent mouse prion protein (PrP) promoter elements ([B6C3- Tg(APP695)3Dbo Tg(PSEN1)5Dbo/J]; Jackson Laboratories) were bred with $\mathrm{MyD} 88^{-1-}$ mouse strain for at least three generations to generate $\mathrm{APP}_{\text {swe }}$ / PS1 mice heterozygous for the MyD88 gene. MyD88 ${ }^{-1-}$ mice (in C57BL/6 background) were provided by S. Akira (Osaka University, Osaka, Japan). All newborn pups were genotyped and included in the different experimental groups. All mouse strains were maintained in a C57BL/6J background and acclimated to standard laboratory conditions. All protocols were conducted according to the Canadian Council on Animal Care guidelines, as administered by the Laval University Animal Welfare Committee.

\section{Fluorescent-activated cell sorting (FACS) analysis}

To analyze the population of monocytes, anti-coagulated whole blood was taken from the facial vein, quickly suspended and cells were washed with DPBS with $4 \%$ of fetal bovine serum (FBS). Cells were then re-suspended into DPBS with $2 \% \mathrm{FBS}$ and incubated on ice with purified rat anti-mouse CD16/CD32 (Mouse BD Fc Bloc, $\mathrm{BD}$ Bioscience). Still on ice, the mix was incubated with $\mathrm{PE}-\mathrm{Cy} 7$ conjugated $\mathrm{CD} 11 \mathrm{~b}$ antibody (eBioscience), APC conjugated CD115 antibody (eBioscience), PerCP cy5.5 conjugated Gr1 antibody (Cerdarlane) and CD45 PECy5 (BD Bioscience) for 45 minutes. Cells were washed again in DPBS with 2\% FBS. Red blood cells were lysed with hemolysin according to manufacturer's protocol (Beckman Coulter, Mervue, Galway, Ireland) and cells were washed with DPBS and re-suspended in equal volumes of DPBS. The cells were analyzed using a twolasers and six color FACS Canto II flow cytometer and data acquisition was done with BD Facs Diva software (Version 6.1.2, BD Biosciences, San Jose, CA). Cells were sorted according to the different fluorescent antibodies. Results were analyzed using Flow Jo software (Tristar).

\section{Tissue collection}

To collect brain tissues for immunofluorescence, mice were deeply anesthetized via an i.p. injection of a mixture of ketamine hydrochloride and xylazine and then were perfused intracardially with ice-cold $0.9 \%$ saline, followed by $4 \%$ paraformadehyde in a $0.1 \mathrm{M}$ borax buffer $\left(\mathrm{pH} 9.5\right.$ at $\left.4^{\circ} \mathrm{C}\right)$. Brains were rapidly removed from skulls, post-fixed in PFA $1-3 \mathrm{~d}$ at $4^{\circ} \mathrm{C}$ and cryoprotected in $10 \%$ sucrose diluted in PFA overnight. The frozen brains were then sectioned into $25-\mu \mathrm{m}$ thick coronal sections using a microtome (Cambridge Instruments Company) and slices were collected in a cold cryoprotectant solution $(0.05 \mathrm{M}$ sodium phosphate buffer, $\mathrm{pH}$ $7.3,30 \%$ ethylene glycol, $20 \%$ glycerol, stored at $-20^{\circ} \mathrm{C}$ ). For protein analysis, brains were decapitated, rapidly removed from the skull and frozen in liquid nitrogen. They were subsequently stored at $-80^{\circ} \mathrm{C}$ until protein extraction and detection.

\section{Stereological analysis}

To stain $A \beta$ plaques, free-floating sections were treated 30 min with a permeabilization/blocking solution 
containing $0.4 \%$ Triton $\mathrm{X}-100,4 \%$ goat serum and $1 \%$ bovine serum albumin (BSA; Sigma-Aldrich) in KPBS. Using the same solution, sections were immunostained 60 min with monoclonal anti-A $\beta$ (6E10, 1:3,000; Chemicon international), washed three times for $5 \mathrm{~min}$ in KPBS and then incubated with secondary antibody goat anti-mouse Cy3 conjugated (1:1,000; Jackson Immunoresearch Laboratories, inc) for $60 \mathrm{~min}$. Stereological analysis was performed as described previously [16]. The contours of the cortex and hippocampus areas were traced as virtual overlay on the steamed images and areas was calculated. For 3 and 6-month-old APP mice, the area occupied by all $A \beta$-labeled plaques was determined. For the analysis of 9-month-old APP mouse plaques, the Stereo Investigator software (Microbrightfield) sequentially chose counting frame in cortex and hippocampus. Areas of analyzed hippocampal or cortex region were calculated as well as areas occupied by plaques in those counting frames.

\section{Protein extraction}

Proteins from hemi-forebrains were extracted using a modified method of the procedure published by Lesne et al. [17]. All manipulations were done on ice to minimize protein degradation. One hemi-forebrain was placed in a $1 \mathrm{ml}$ syringe with a $20 \mathrm{G}$ needle. $500 \mu \mathrm{l}$ of buffer A $(50 \mathrm{mM}$ Tris- $\mathrm{HCl} \mathrm{pH} 7.6,0.01 \% \mathrm{NP}-40$, $150 \mathrm{mM} \mathrm{NaCl}, 2 \mathrm{mM}$ EDTA, 0.1\% SDS, $1 \mathrm{mM}$ phenylmethylsulfonyl fluoride (PMSF), protease inhibitor cocktail) were added and 10 up and down were made to homogenize the tissue, followed by a 5 minutes centrifugation at $3000 \mathrm{RPM}$ at $4^{\circ} \mathrm{C}$. The supernatant (extracellular proteins enriched fraction) was then collected and frozen at $-80^{\circ} \mathrm{C}$. The insoluble pellet was suspended in $500 \mu \mathrm{l}$ TNT-buffer (Buffer B; 50 mM Tris-HCl pH 7.6, $150 \mathrm{mM} \mathrm{NaCl}, 0.1 \%$ Triton X-100, $1 \mathrm{mM}$ PMSF, protease inhibitor cocktail), followed by a 90 minutes centrifugation at $13000 \mathrm{RPM}$ at $4^{\circ} \mathrm{C}$. The supernatant (cytoplasmic proteins enriched fraction) was then collected and frozen at $-80^{\circ} \mathrm{C}$. The pellet was suspended in $500 \mu$ l buffer $\mathrm{C}(50 \mathrm{mM}$ Tris- $\mathrm{HCl} \mathrm{pH} 7.4,150 \mathrm{mM}$ $\mathrm{NaCl}, 0.5 \%$ Triton X-100, 1 mM EGTA, 3\% SDS, 1\% deoxycholate, $1 \mathrm{mM}$ PMSF, protease inhibitor cocktail) and incubated at $4^{\circ} \mathrm{C}, 50 \mathrm{RPM}$, for 1 hour. The samples were centrifuged for 90 minutes at $13000 \mathrm{RPM}$ and $4^{\circ} \mathrm{C}$ and the supernatant (membrane proteins enriched fraction) was collected and frozen at $-80^{\circ} \mathrm{C}$. Protein concentration of each fraction was determined using the Quantipro BCA assay kit (Sigma) according to the manufacturer protocol.

\section{Detection of total $A \beta$ levels by Western blot}

For total A $\beta$ detection by Western blot, 10-30 $\mu \mathrm{g}$ of extracellular protein fractions were separated on a precast $10-20 \%$ SDS polyacrylamide Tris-Tricine gel (Bio-Rad). Separated proteins were then transferred onto polyvinylidene fluoride (PVDF) membranes (PerkinElmer Life and Analytical Sciences) and detected by Western blotting. Blots were probed with a mouse antiamyloid beta protein monoclonal antibody clone $6 \mathrm{E} 10$ (1:1000, Covariance) in Tris-buffered saline with $0.05 \%$ Tween 20 (TBS-T) and 5\% skim milk. Blots were visualized using anti-mouse secondary antibody tagged with horseradish peroxidase (1:1000; Jackson ImmunoResearch) and ECL Plus Detection Reagents (GE Healthcare). Membranes were stripped in $25 \mathrm{mM}$ glycine- $\mathrm{HCl}$, $\mathrm{pH} 2.0$, containing $1 \%$ SDS to allow $\beta$-actin revelation using first a mouse $\beta$-actin antibody (MAB1501, 1:10 000; Millipore Bioscience Research Reagents) and then a goat anti-mouse peroxidase conjugated secondary antibody (1:10 000; Jackson ImmunoResearch). Semi-quantitative analysis of signal was performed under a Northern Light Desktop Illuminator (Imaging Research) using a Sony Camera Video System and the NIH Image J software version 1.32J. Optical values were normalized according to the $\beta$-actin loading control.

\section{RNA extraction and quantitative real-time PCR (Q-PCR)}

Tissue samples were homogenized in Qiazol buffer (Qiagen) and extracted using the RNeasy mini kit with on-column DNase (Qiagen) treatment following the manufacturer's recommendations. RNA concentration was measured using a NanoDrop spectrophotometer (Thermo Scientific) and quality was assessed with an Agilent 2100 Bioanalyzer (Agilent Technologies Inc). First-strand cDNA synthesis was accomplished using $5 \mu \mathrm{g}$ of isolated RNA in a reaction containing $200 \mathrm{U}$ of Superscript III Rnase H-RT (Invitrogen Life Technologies), $300 \mathrm{ng}$ of oligo- $\mathrm{dT}_{18}, 50 \mathrm{ng}$ of random hexamers, $50 \mathrm{mM}$ Tris- $\mathrm{HCl} \mathrm{pH} 8.3,75 \mathrm{mM} \mathrm{KCl}, 3 \mathrm{mM} \mathrm{MgCl}_{2}$, $500 \mu \mathrm{M}$ deoxynucleotides triphosphate, $5 \mathrm{mM}$ dithiothreitol, and $40 \mathrm{U}$ of Protector RNase inhibitor (Roche Diagnostics) in a final volume of $50 \mu \mathrm{l}$. The reaction was performed at $25^{\circ} \mathrm{C}$ for 10 minutes following at $50^{\circ} \mathrm{C}$ for 1 hour and then treated with $1 \mu \mathrm{g}$ of RNase A for $30 \mathrm{~min}$ at $37^{\circ} \mathrm{C}$. The resulting products were purified with Qiaquick PCR purification kits (QIAGEN). cDNA corresponding to $20 \mathrm{ng}$ of total RNA was used to perform fluorescent-based Realtime PCR quantification using the LightCycler 480 (Roche). The following sets of sense/antisense primers were used: for MyD88: 5'-TCCGGCAACTAGAACAGACAGACT-3'/5'-GCGG CGACACCTTTTCTCAAT-3', IL-1 $\beta$ : 5' - TCAAATCT CGCAGCAGCACATC-3'/5'-CCAGCAGGTTATCATCATCATCCC-3', 18S: 5'-TGGATACCGCAGCTAGGA ATAATG-3'/5'-TCACCTCTAGCGGCGCAATAC-3', Hprt1: 5'-CAGGACTGAAAGACTTGCTCGAGAT-3'/ 5'-CAGCAGGTCAGCAAAGAACTTATAGC-3'. 
Reagent LightCycler 480 SYBRGreen I Master was obtained from the same company and was used as described by the manufacturer. The conditions for PCR reactions for 45 cycles were: denaturation at $95^{\circ} \mathrm{C}$ for $10 \mathrm{sec}$, annealing at $60^{\circ} \mathrm{C}$ for $10 \mathrm{sec}$ and elongation at $72^{\circ} \mathrm{C}$ for $12 \mathrm{sec}$. The reaction was then heated for $5 \mathrm{sec}$ at $2^{\circ} \mathrm{C}$ lower than the melting temperature of the DNA fragment. Reading of the fluorescence signal was taken at the end of the heating to avoid non-specific signal. A melting curve was performed to assess non-specific signal. Oligoprimer pairs that allow the amplification of approximately $200 \mathrm{bp}$ were designed by GeneTools software (Biotools Inc) and their specificity was verified by blast in the GenBank database. Data calculation and normalization was performed using second derivative method as described previously [18] using the reference genes hypoxanthine guanine phosphoribosyl transferase 1 (Hprt1) and 18S ribosomal RNA (18S). PCR amplification efficiency was verified.

\section{Behavioral analysis}

Mice were housed four or five per cage in a colony maintained in a room under natural lighting conditions with a 14/10 hr light-dark cycle (on at 6:00) and tested during the "light on" phase of the day. Food and water were provided ad libitum. Behavioral experimenter was blinded to the genotype of animals. The behavioral and general health of mice was monitored using a modified version of the primary observation screen described by the SHIRPA protocol [19]. The spatial learning abilities of mice were assessed in the T-water maze task (TWM). The T-maze apparatus (length of stem $64 \mathrm{~cm}$, length of arms $30 \mathrm{~cm}$, width $12 \mathrm{~cm}$, height of walls $16 \mathrm{~cm}$ ) was made of clear fiberglass and filled with water $\left(23 \pm 1^{\circ} \mathrm{C}\right)$ at a height of $12 \mathrm{~cm}$. An escape platform $(11 \times 11 \mathrm{~cm})$ was placed at the end of the target arm and was submerged $0.5 \mathrm{~cm}$ below the surface. The acquisition phase allows to evaluate animals for left-right spatial learning. During the first two trials, platforms were placed on each arms of the TWM. In order to assess arm preferences, the least chosen arm was reinforced by water escape. The mice were placed in the stem of the $\mathrm{T}$ maze and choose to swim either left or right until they found the submerged platform and escape to it, to a maximum of $60 \mathrm{~s}$. After reaching the platform, the mice were allowed to stay on it for $20 \mathrm{~s}$ and then were immediately placed back in the maze. If the animals did not find the platform within this limit, they were gently guided onto it. Repeated trials were presented on the same day up to a maximum of 48 trials. A rest period of at least 10-15 min intervened between each block of 10 trials. A mouse was considered to have learned the task when it made no errors in a block of five consecutive trials. The reversal learning phase was then conducted
48 hours later. During this phase the same protocol was repeated, except that the mice were trained to find the escape platform on the opposite side to that on which they had learned on acquisition phase. Two measures were taken: number of trials to reach the criterion (5 of 5 correct choices made on consecutive trials) and escape latency.

\section{Statistical analysis}

All statistical analysis was performed using the SPSS software (SPSS 15.0). Homogeneity of variance in our different samples was performed with the Levene's test and $p<0.05$ was set as the level of a significant difference.

\section{Results}

\section{Reduced expression of MyD88 adaptor protein in} $\mathrm{APP}_{\text {swe }} / \mathrm{PS} 1$ mice increased memory deficits

As the brain tissue macrophage, microglia expresses a wide range of TLRs to detect exogenous and endogenous ligands. It is now well known that microglia use these receptors to recognize and phagocyte $A \beta$ peptides. We and others previously demonstrated that the TLR2 is necessary for the microglia to mount an inflammatory reaction against $A \beta[13,20,21]$. When stimulated, TLRs activate intracellular signaling cascade via the adaptor protein MyD88. We show here that MyD88 mRNA expression is upregulated in response to $A \beta$ (Figure 1a). Indeed, quantitative real-time PCR (Q-PCR) analysis of 6 month-old $\mathrm{APP}_{\text {swe }} / \mathrm{PS} 1$ mice revealed a significant increase in MyD88 mRNA compared to WT littermates. To study the role of this major signaling protein, we attempted to breed the $\mathrm{APP}_{\text {swe }} / \mathrm{PS} 1$ mouse with the MyD88 knockout mice, which share the same background. Unfortunately, $\mathrm{APP}_{\text {swe }} / \mathrm{PS} 1$ mice lacking the MyD88 adaptor protein were not viable. $\mathrm{APP}_{\text {swe }} / \mathrm{PS} 1$ mice heterozygous for the MyD88 gene were therefore used for further analyses. By 3 months of age, MyD88 mRNA levels in the brain of $\mathrm{APP}_{\text {swe }} / \mathrm{PS} 1-\mathrm{MyD} 8^{+/-}$mice were reduced of $66 \%$ compared to those of $\mathrm{APP}_{\text {swe }} / \mathrm{PS} 1$ mice as determined by Q-PCR (Figure 1b). Arbitrary values obtained for $\mathrm{APP}_{\text {swe }} / \mathrm{PS} 1$ and $\mathrm{APP}_{\text {swe }} / \mathrm{PS} 1-\mathrm{MyD} 88$ + - groups were $4.90 \pm 1.02$ and $1.66 \pm 0.11$. As expected,

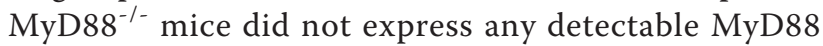
mRNA (arbitrary value: $0.18 \pm 0.03$ ).

We next evaluated $\mathrm{APP}_{\text {swe }} / \mathrm{PS} 1-\mathrm{MyD} 88^{+/-}$mice in the $\mathrm{T}$-water maze for behavioral evaluation. Hippocampusbased spatial learning and memory was assessed by the ability of mice to acquire (training session) and retrieve (test session) spatial information as indicative of learning and memory functions. Escape latency and mean of trials to reach the hidden platform placed on one arm of the maze were recorded. Mice that have found and climbed onto the hidden platform on five consecutive 

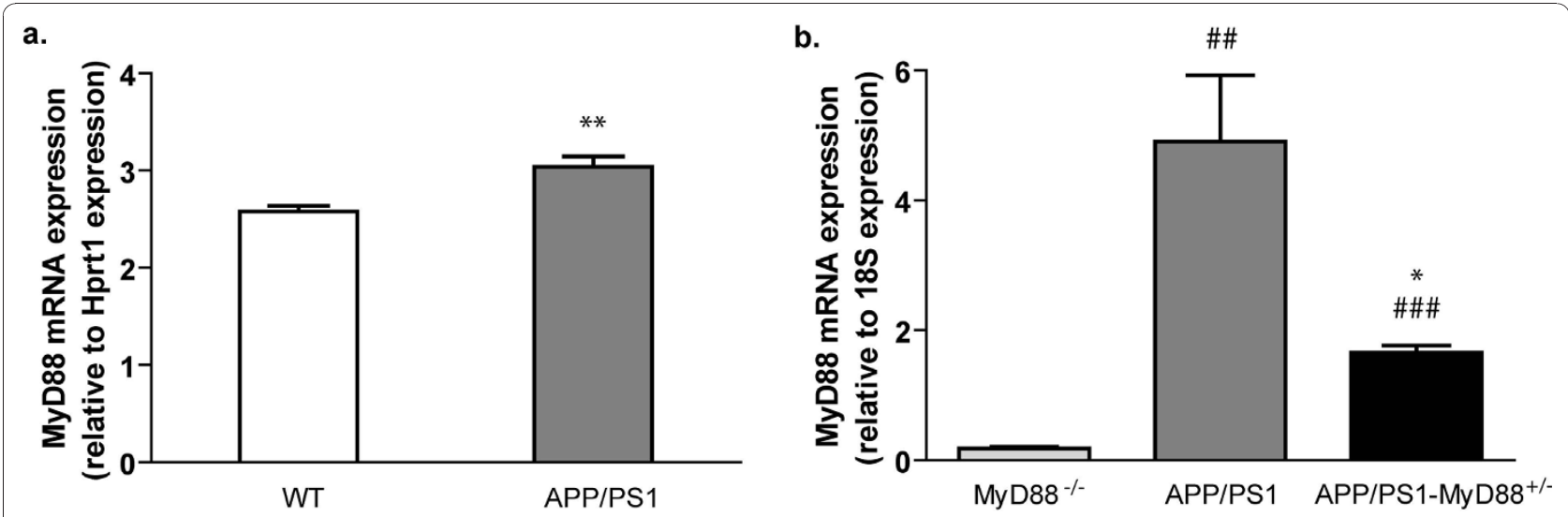

Figure 1 Relative expression of MyD88 expression in the brain of different mouse strains. (a) MyD88 mRNA expression is upregulated in 6 month-old APP swe/PS1 mice compared to WT littermates. ${ }^{* *} P<0.05$ (vs WT) (b) APP swe $_{\text {SPS1-MyD88 }}{ }^{+/-}$mice expressed significantly lower level of MyD88 mRNAs compared to APP swe $_{\text {PS1 }}$ mice at 3 months of age. \#\# $P<0.01$, \#\#\# $P<0.001$ (vs MyD88 ${ }^{-1}$ ); ${ }^{*} P<0.05$ (vs APP swe/PS1). Data are expressed as mRNA arbitrary units normalized with housekeeping genes Hprt1 and 18S. Error bars: SEM; $n=3-4$. (Statistical analysis was performed using Student's t-test in (a) and a one-way ANOVA followed by a Bonferroni post-hoc test in (b)).

trials were considered to have reached the criterion. During the initial training session, all groups exhibited comparable performance, as demonstrate by the numbers of errors (Figure 2a) and time spent (Figure 2c) to learn the task. No significant differences in term of swimming performance or motivation were detected between each group of mice. We performed a probe trial $48 \mathrm{~h}$ after completing the initial training to evaluate the cognitive flexibility of our different mouse strains. The hidden platform was placed on the opposite arm of

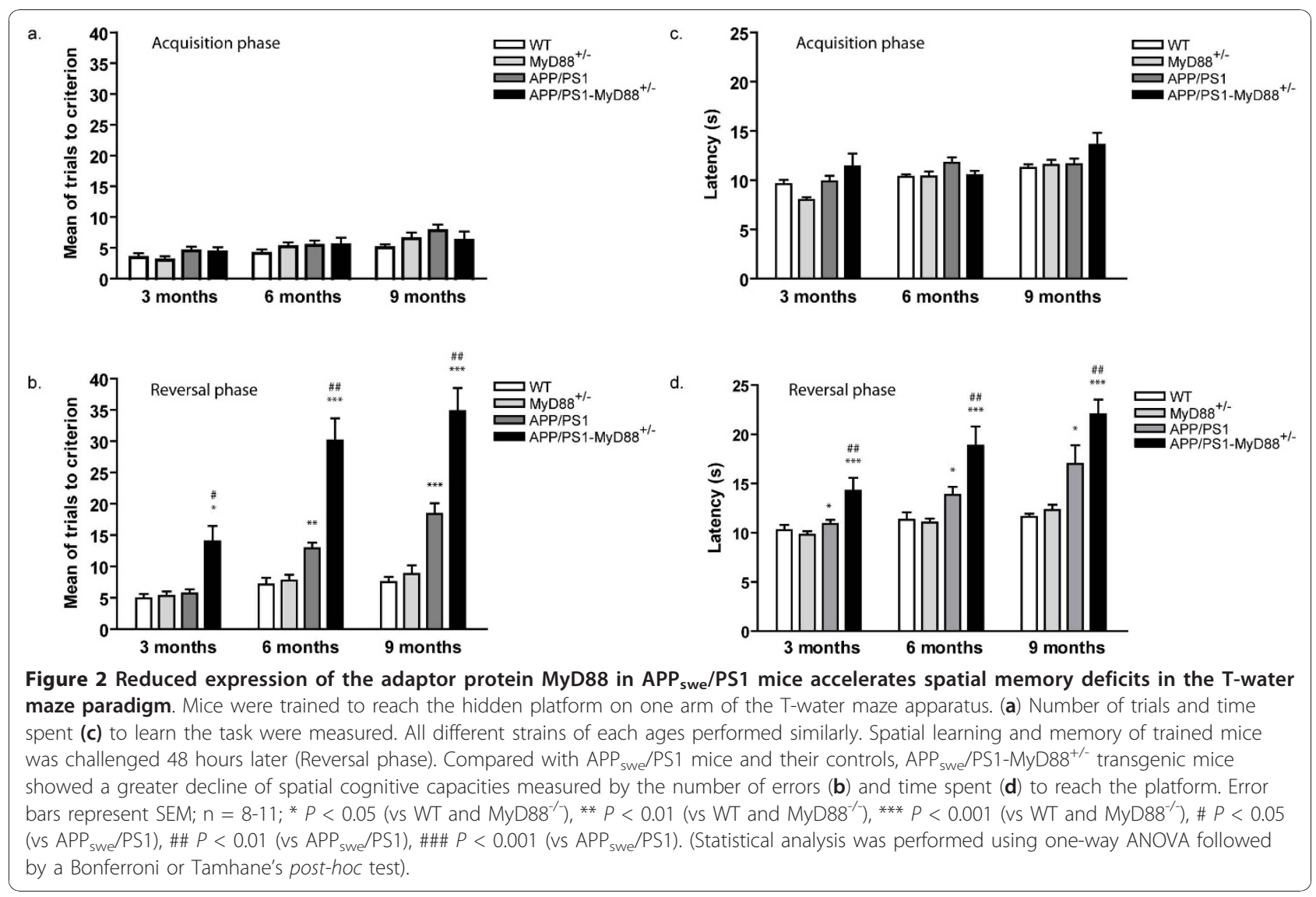


the T-maze apparatus and mice were placed back in the maze. Both wild-type and MyD $88^{+/-}$mice showed equally successful latency and number of trials to criterion during the reversal task. Because of their behavioral phenotype, $\mathrm{APP}_{\text {swe }} / \mathrm{PS} 1$ mice demonstrate signs of cognitive deficits at 6 and 9 months of age compared to controls. The decreased expression of MyD88 gene in $\mathrm{APP}_{\text {swe }} / \mathrm{PS} 1$ transgenic mice resulted in a significant decline in memory as indicated by longer latencies (Figure 2d) and increased number of errors committed (Figure 2b) to reach the platform during the probe trial, compared to results obtained for $\mathrm{APP}_{\text {swe }} / \mathrm{PS} 1$ mice. Those cognitive deficits began as early as 3 months $\left(5.7 \pm 0.6\right.$ trials and $11.0 \pm 0.5$ seconds for $\mathrm{APP}_{\text {swe }} / \mathrm{PS} 1$ vs $14.2 \pm 2.4$ trials and $14.0 \pm 1.3$ seconds for $\mathrm{APP}_{\text {swe }} /$ PS1-MyD88 $\left.{ }^{+/-}\right)$and evolved rapidly at 6 (13.0 \pm 1.0 trials and $13.5 \pm 0.7$ seconds for $\mathrm{APP}_{\text {swe }} / \mathrm{PS} 1$ mice vs $30.1 \pm 3.5$ trials and $18.9 \pm 1.9$ seconds for $\mathrm{APP}_{\text {swe }} / \mathrm{PS} 1-\mathrm{MyD}^{+/-}$ mice) and 9 months $(18.4 \pm 1.7$ trials and $17.0 \pm 1.9 \mathrm{sec}-$ onds for $\mathrm{APP}_{\text {swe }} / \mathrm{PS} 1$ vs $34.7 \pm 3.7$ trials and $22.0 \pm 1.5$ seconds for $\mathrm{APP}_{\text {swe }} / \mathrm{PS} 1-\mathrm{MyD} 88^{+/-}$). These results demonstrate that the reduce expression of MyD88 in $\mathrm{APP}_{\text {swe }} / \mathrm{PS} 1$ mice result in a greater cognitive deficit as depicted by accelerated spatial memory impairment. These data suggest that MyD88 signaling plays an important role in microglia activation in order to fight against AD evolution.

\section{$A \beta$ plaques accumulate slower in brains of

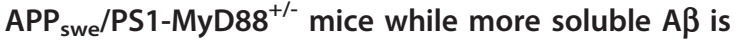 detected}

As amyloid plaques are a neuropathological marker of $\mathrm{AD}$, we compared amyloid plaque load in $\mathrm{APP}_{\text {swe }} / \mathrm{PS} 1$ and $\mathrm{APP}_{\text {swe }} / \mathrm{PS} 1-\mathrm{MyD} 88^{+/-}$. A $\beta$ immunoreactivity was measured with the monoclonal $6 \mathrm{E} 10$ antibody specific for the fragment 1-17 a.a. of the human $A \beta$ peptide in brain coronal section. Area of $A \beta$ deposits was evaluated in the cortex and hippocampus by stereological analysis in two similar sections per animal and percentage area occupied by plaques was calculated (Figure 3a). At three months of age, no statistically significant difference in area occupied by plaques was observed between $\mathrm{APP}_{\text {swe }} /$ PS1 and in $\mathrm{APP}_{\text {swe }} / \mathrm{PS} 1-\mathrm{MyD} 88^{+/-}$mice $(0.007 \pm 0.002 \%$ and $0.002 \pm 0.0006 \%$, respectively). At six and nine months, $\mathrm{A} \beta$ deposits were significantly lower in $\mathrm{APP}_{\text {swe }} /$ PS1-MyD88 $8^{+/-}$brains compared to their $\mathrm{APP}_{\text {swe }} / \mathrm{PS} 1$ littermates $(0.292 \pm 0.054$ vs $0.116 \pm 0.021,1.208 \pm 0.135$ vs $0.769 \pm 0.075,6$ and 9 month-old $\mathrm{APP}_{\text {swe }} / \mathrm{PS} 1$ and $\mathrm{APP}_{\text {swe }} / \mathrm{PS} 1-\mathrm{MyD}^{+/-}$, respectively).

Since A $\beta$ plaques did not correlate with cognitive deficits, we decided to measure soluble levels of $A \beta$ species in brains of 6 month-old mice - there is accumulating evidence associating soluble $\mathrm{A} \beta$ oligomers with cognitive impairments $[2,17,22,23]$. The amounts of different $A \beta$ species were analyzed in extracellular (Figure $3 \mathrm{~b}$ ), intracellular (Figure 3c) and membrane-associated (Figure 3d) enriched protein fractions by western blots, based on the method developed by Lesne et al. [17]. Proteins from wild-type animals were used as control to assess the specificity of the antibody and the signal was barely detectable in such a case (data not shown). In general, most $A \beta$ oligomers were increased in the brain of $\mathrm{APP}_{\text {swe }} / \mathrm{PS} 1$ $\mathrm{MyD}^{+/-}$mice compared to that of $\mathrm{APP}_{\text {swe }} / \mathrm{PS} 1$. Indeed, there were significantly higher levels of $A \beta$ oligomers in extracellular (1-, 6- and 12-mer), intracellular (3- and 6-mer) and membrane-associated (1-, 3-, 6-, 9-mer) enriched proteins fractions. Levels of sAPPa levels and APP full length (APPfl) were also significantly higher in brains of $\mathrm{APP}_{\text {swe }} / \mathrm{PS} 1-\mathrm{MyD}^{+/-}$mice in intracellular and membrane-associated enriched proteins, respectively. These data indicate that soluble oligomeric $A \beta$ levels increased while the amyloid- $\beta$ plaque load decreased in brains of AD mice that had down-regulated MyD88 gene expression.

\section{Inflammatory monocyte subset is decreased while resident monocytes are increased in the blood of $\mathrm{APP}_{\text {swe }} / \mathrm{PS1-MyD88^{+/- }}$ mice}

It has been established that there is two principal blood monocyte populations that possess different migratory properties: the "inflammatory subset" which is characterized by a $\mathrm{CX}_{3} \mathrm{CR}_{1}{ }^{\mathrm{Lo}} \mathrm{CCR} 2^{+} \mathrm{Gr} 1^{+}$phenotype and the "resident subset" categorized by $\mathrm{CX}_{3} \mathrm{CR}_{1}{ }^{\mathrm{Hi}} \mathrm{CCR} 2^{-} \mathrm{Gr} 1^{-}$ [24]. To evaluate if these two subsets of monocytes were different in animals with reduced MyD88 protein, we measured expression levels of Gr1 surface marker on monocytes of 3-4 month-old mice. To analyze leukocytes in blood cells, we included only cells that were positive for CD45 (Figure 4a). Then, CD $45^{+} \mathrm{CD} 11 \mathrm{~b}^{+} \mathrm{CD} 115^{+}$cells were selected and considered as the population of monocytes (Figure 4b). There was no significant difference between percentages of monocytes (Figure 4b) or CD $45^{+}$ cells (data not shown) among the 4 groups. Relative proportions of $\mathrm{Gr}^{+}$and $\mathrm{Gr} 1^{-}$cells were then evaluated in the monocyte population (Figure 4c). There was significantly less $\mathrm{Gr}^{+}$and more $\mathrm{Gr} 1^{-}$cells in $\mathrm{APP}_{\text {swe }} / \mathrm{PS} 1$ -

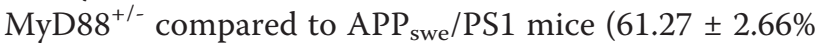
vs $68.80 \pm 2.04 \%$ and $39.58 \pm 2.81 \%$ vs $31.26 \pm 2.04 \%$, respectively). To evaluate the global difference between these two populations of monocytes, the ratios of $\mathrm{Gr}^{+}$ monocytes on $\mathrm{Gr}^{-}$monocytes were calculated (Figure $4 \mathrm{~d}$ ). These ratios revealed a significant decrease for $\mathrm{APP}_{\text {swe }} /$ PS1-MyD88 $8^{+/-}$mice compared to their $\mathrm{APP}_{\text {swe }} / \mathrm{PS} 1$ control $(1.57 \pm 0.19 \%$ vs $2.25 \pm 0.21 \%$, respectively) These results suggest that MyD88 pathway has a significant impact on blood monocyte populations in this 
a.
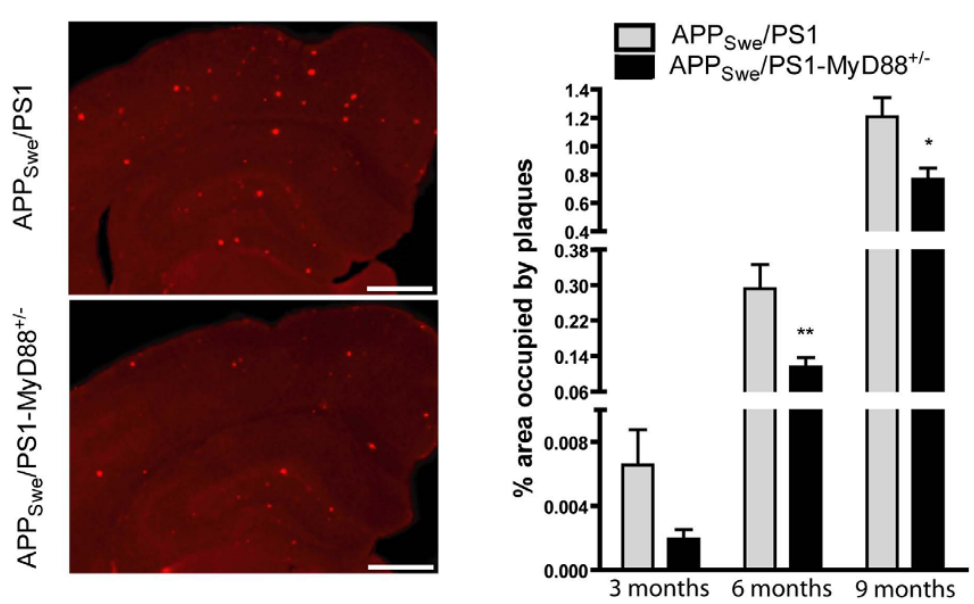

b.

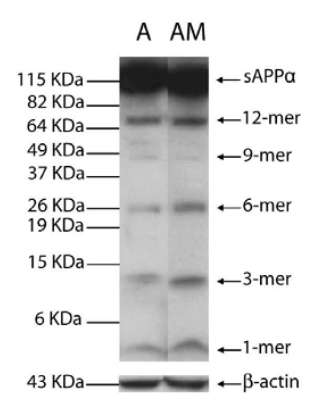

Extracellular-enriched proteins

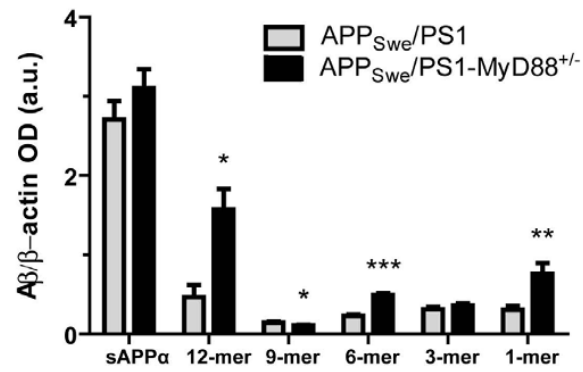

c.

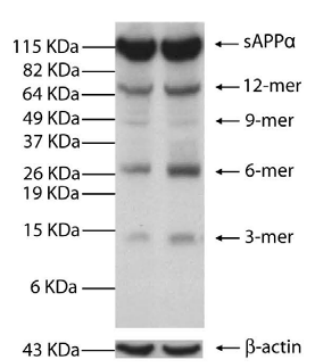

d.

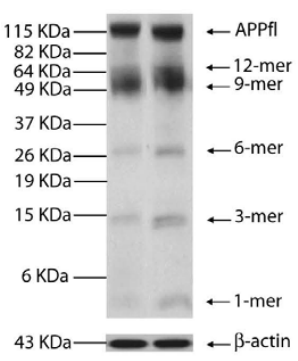

Intracellular-enriched proteins

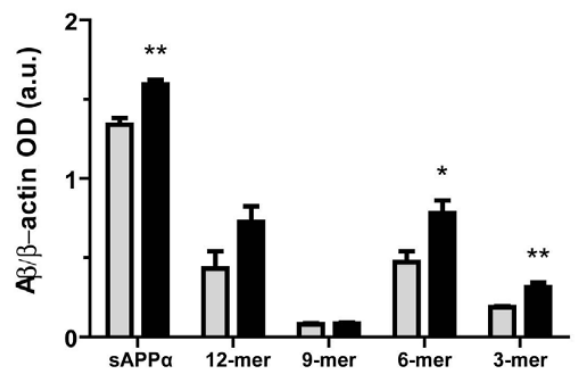

Membrane-associated proteins

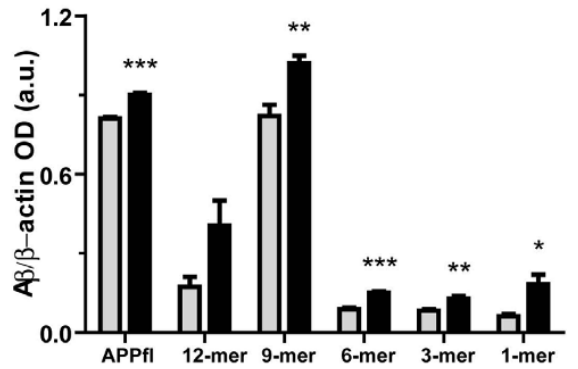

Figure 3 Amyloid plaque load and soluble $A \beta$ levels in the brain of APP $_{\text {swe }} / P S 1$ in a context of partial MyD88 deficiency. Deposition of $A \beta$ plaques is significantly more abundant in 6 and 9 month-old APP swe $/ P S 1$ compared to APP swe/PS1-Myd88 ${ }^{+/}$mice (a). A 3 immunoreactivity in cortex and hippocampus is shown in brain sections of 9 month-old APP swe $/ P S 1$ and APP swe $_{\text {PS1-Myd88 }}{ }^{+-}$mice. Percentage of area covered by plaques was quantified for mice of 3, 6 and 9 month-old, respectively. $n=9-10$. (Two-way ANOVA was performed revealing a significant interaction between factors age and genotype. The comparison of genotype for each age was performed by Student's $t$-test). To detect soluble $A \beta$, western blot analysis on 10-20\% Tris-Tricine denaturing polyacrylamide gels of extracellular (b), intracellular (c) and membrane-associated (d) enriched proteins of 6 month-old mice were assessed using monoclonal 6 E10 antibody to reveal the different species. Most of A $\beta$ oligomers

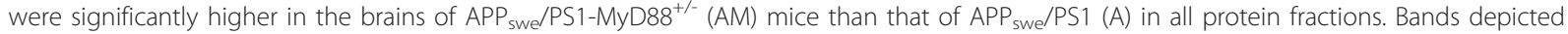
here were cut from the same membrane for each protein fraction. Values are expressed as optical densities (OD) in arbitrary units (a.u.) of $A \beta$ normalized with $\beta$-actin. $\mathrm{n}=4-7$; Student's $t$-test; ${ }^{*} P<0.05$, ** $P<0.01,{ }^{* * *} P<0.001$. Error bars: SEM. Scale bar $=500 \mu \mathrm{m}$. 


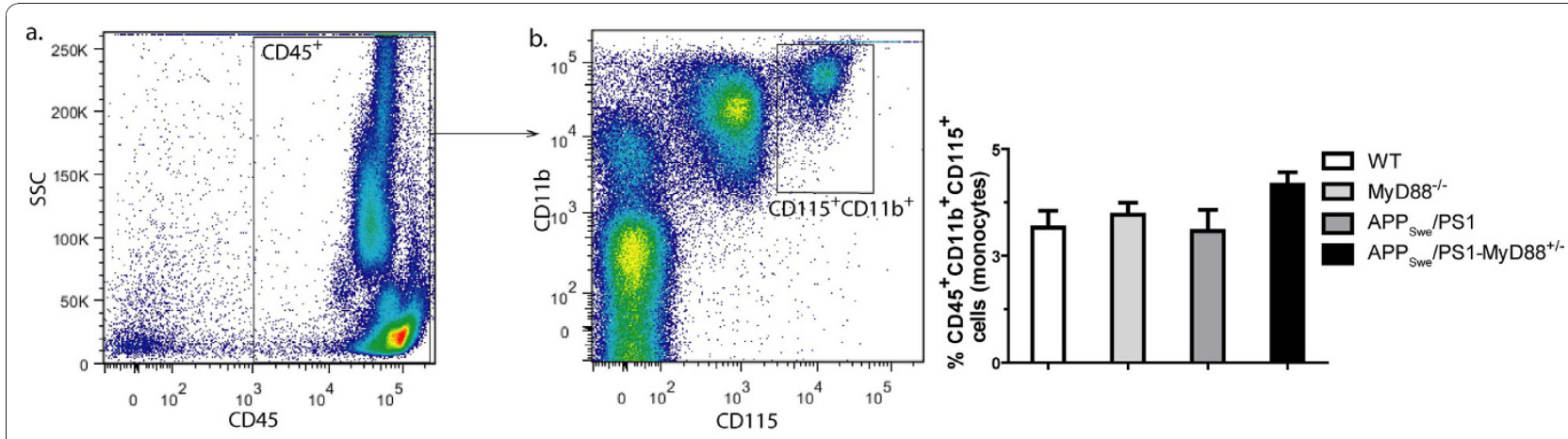

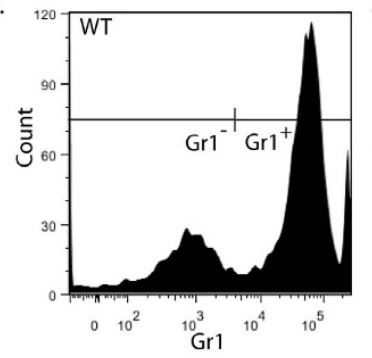
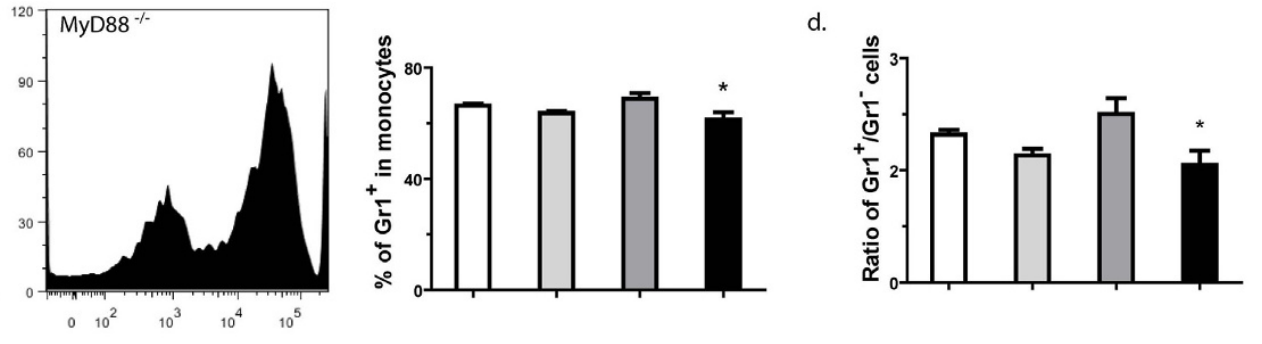
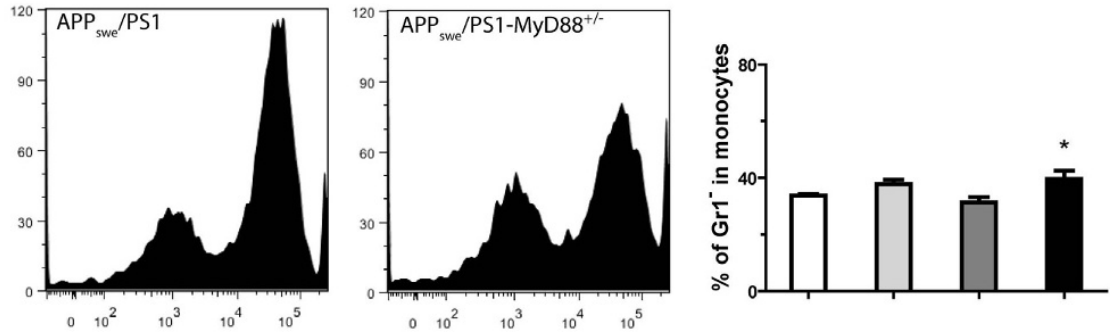

Figure 4 Flow cytometry analysis of blood monocyte subsets in WT, MyD88 ${ }^{-/-}$, APP $_{\text {swe }} /$ PS1 and APP swe $/$ PS1-MyD88 $^{+/-}$mice. Blood taken from the facial vein of 3-4 month-old mice was analyzed by FACS with the following fluorescently-labeled antibodies: CD45, CD11b, CD115 and Gr1. Leukocyte population is represented as cells in the CD45 gate (a). To analyze exclusively monocytes in CD $45^{+}$cells, CD $11 b^{\text {hi }}$ and CD11 hi $\left(C D 45^{+} \mathrm{CD} 11 \mathrm{~b}^{+} \mathrm{CD} 115^{+}\right)$cells were gated and the total percent for each group was quantified (b). No significant change in number of monocytes was revealed. Representatives histograms of monocytes for each group and their mean relative $\mathrm{Gr}^{+}{ }^{+}$and $\mathrm{Gr} 1^{-}$values (c) showed significantly less $\mathrm{Gr}^{+}$and more $\mathrm{Gr} 1^{-}$monocytes in APP swe $/ \mathrm{PS} 1-\mathrm{MyD} 88^{+/-}$mice compare with $\mathrm{APP}_{\text {swe }} / \mathrm{PS} 1$ mice. This difference is even more noticeable while expressing the ratio of $\mathrm{Gr}^{+}{ }^{+}$on $\mathrm{Gr} 1^{-}$monocytes (d). Error bars: SEM; $\mathrm{n}=3-5 ;{ }^{*} \mathrm{P}<0.05$ (vs APP swe/PS1). (Statistical analysis was performed using one-way ANOVA followed by a Dunnett's or Tamhane's post-hoc test).

mouse model of AD, which exhibits increased amount of the resident subset and a decreased level of inflammatory monocytes in a context of partial MyD88 deficiency.

\section{IL-1 $\beta$ gene expression is decreased in the brain of $\mathrm{APP}_{\text {swe }} / \mathrm{PS} 1-\mathrm{MyD}^{+/ /-}$mice}

We finally investigated the inflammatory status in the brains of $\mathrm{APP}_{\text {swe }} / \mathrm{PS} 1-\mathrm{MyD} 88^{+/-}$mice by measuring the mRNA levels of the pro-inflammatory cytokine IL-1 $\beta$ (Figure 5). A significant increase in IL- $1 \beta$ gene expression was found in the brain of $\mathrm{APP}_{\text {swe }} / \mathrm{PS} 1$ mice, which was essentially abolished in a context of MyD88 deficiency. IL-1 $\beta$ gene expression levels were significantly higher in $\mathrm{APP}_{\text {swe }} / \mathrm{PS} 1$ mice than all other groups of mice $((6,84 \pm 1,16$ vs $4,00 \pm 0,30$ (WT), 3,77 $\pm 0,47$

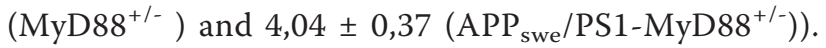

These data suggest that MyD88 plays a very important role to regulate IL- $1 \beta$ gene transcriptional activation in presence of $\mathrm{A} \beta$ in this mouse model of $\mathrm{AD}$.

\section{Discussion}

$\mathrm{A} \beta$ accumulation is suggested to be a key event leading to development and progression of AD. Production of these toxic proteins is associated with neuronal apoptosis, reactive astrocytes, activated microglia and production of inflammatory molecules. Innate immune response plays a crucial role in the course of AD. However, the exact role of activated microglia is still under debate. These cells can release neurotoxic mediators or can be neuroprotective in promoting the clearance of toxic $A \beta$ from the brain. Several lines of evidence have shown that microglia activated via TLRs can induce 


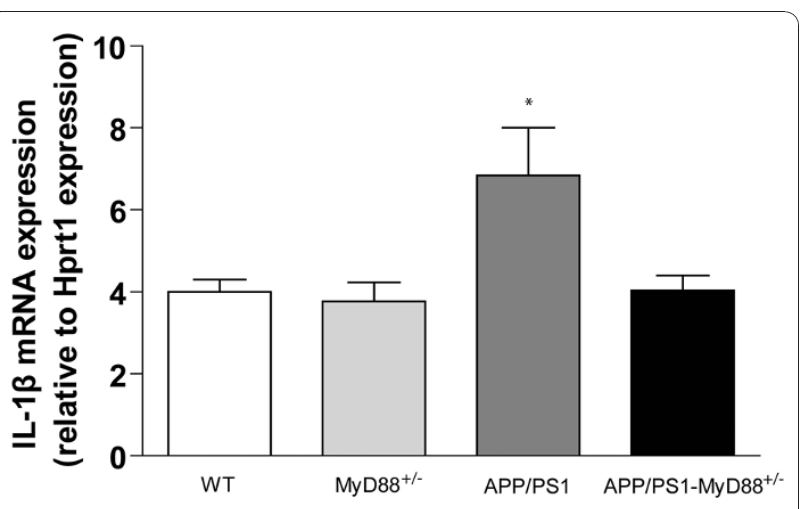

Figure 5 Decreased IL-1 $\beta$ gene expression in the brain of controls and $\mathrm{APP}_{\text {swe }} / \mathrm{PS} 1-\mathrm{MyD} 88^{+/-}$mice. Quantification of IL-1 $\beta$ mRNA expression by Q-PCR of 6 month-old mice revealed significant differences between the different mouse strains. Indeed, higher brain IL-1 $\beta$ mRNA levels were found in $\mathrm{APP}_{\text {swe }} / \mathrm{PS} 1$ mice compared to those measured in WT, MyD88 $8^{+/}$and $\mathrm{APP}_{\text {swe }} / \mathrm{PS} 1$ MyD88 ${ }^{+/}$mice. Error bars: SEM; $n=4-7 ;{ }^{*} P<0,05$ (significantly different from the other groups). (Statistical analysis was performed using one-way ANOVA followed by a Bonferroni post-hoc test).

beneficial effects on AD progression. We have previously demonstrated that TLR2 is important to delay the cognitive decline in a mouse model of AD [21]. The role of TLR2 in microglial activation was also highlighted in the study from Jana et al. [20]. A small proportion of microglia in $\mathrm{APP}_{\text {swe }} / \mathrm{PS} 1$ mice brain expresses TLR2 mRNA, which is a reliable index of pro-inflammatory signaling in myeloid cells $[20,21]$. Other induced innate immune receptors in AD brains include CD14, TLR4, TLR5, TLR7 and TLR9 [9,20,25-28]. Phagocytosis of $A \beta$ by activated microglia is significantly increased in presence of ligands that activate TLRs [11,29-31]. A functional interaction was also demonstrated between fibrillar $A \beta_{1-42}$ peptides and the innate receptor CD14 and this interaction resulted in microglial activation [25]. Furthermore TLR2, TLR4 and CD14 are involved in fA $\beta$ phagocytosis [13]. Activation of TLR/MyD88 pathway may therefore act as a natural defense mechanism in presence of toxic $A \beta$ and restrict disease progression.

Quantification of MyD88 mRNA revealed an upregulation of this gene in response to $\mathrm{A} \beta$ as depicted by a significant increase in $\mathrm{APP}_{\text {swe }} / \mathrm{PS} 1$ mice compared to WT. This suggests a potential function of this gene in AD. To study the role of MyD88 in AD, we used MyD88 knockout mice. Unfortunately, $\mathrm{APP}_{\text {swe }} / \mathrm{PS} 1$ mice deficient in MyD88 gene were not viable. This suggests that MyD88 signaling cascade acts as a natural defense mechanism to prevent $A \beta$ toxicity in this transgenic model, even during mouse development. However it will be important in future studies to test the effects of MyD88 deficiency in other mouse models of $\mathrm{AD}$, because the possibility remains that such a lethally depends on the mouse lines used in this study.

Thus, we created $\mathrm{APP}_{\text {swe }} / \mathrm{PS} 1$ mice heterozygous for the MyD88 gene. This model showed a significant decreased expression of the MyD88 transcript. In our previous report, we have shown that $\mathrm{APP}_{\text {swe }} / \mathrm{PS} 1$ mice deficient in TLR2 expression accelerated spatial and contextual memory impairments. Here, we demonstrate that a reduction in MyD88 expression also induced such behavioral impairments. Analysis of hippocampus-based spatial working learning was assessed in $\mathrm{T}$-water maze. In this behavioral test, the submerged platform is the positive reinforcement. Mice were first trained to learn the position of the platform in the maze. Forty-eight hours later their reversal learning abilities were then challenged, as the submerged platform was placed at the opposite side of the maze. $\mathrm{APP}_{\text {swe }} / \mathrm{PS} 1-\mathrm{MyD}^{+/-}$mice were impaired in reversal training, as seen with a higher delay and number of errors made to reach the criterion compared to $\mathrm{APP}_{\text {swe }} / \mathrm{PS} 1$ mice. These data demonstrate the importance of the MyD88-dependent pathway in a context of memory impairment induced by $A \beta$.

Area occupied by amyloid- $\beta$ plaques was calculated in the brain of $\mathrm{APP}_{\text {swe }} / \mathrm{PS} 1-\mathrm{MyD} 88^{+/-}$mice. We found that disease severity demonstrated by behavioral impairment in the T-water maze did not correlate well with plaque load in the brain. Indeed, $\mathrm{APP}_{\text {swe }} / \mathrm{PS} 1-\mathrm{MyD} 88^{+/-}$mice had fewer plaques at 6 and 9 months compared to $\mathrm{APP}_{\text {swe }} / \mathrm{PS} 1$ mice. Historically, accumulation of $\mathrm{A} \beta$ plaques was indicative of $A D$ progression in human and mouse models. However, as mentioned above, accumulating evidence suggests that soluble and small oligomeric forms of $A \beta$ within human brain is more closely associated with disease severity [2]. Soluble $A \beta$ in different protein pools has deleterious effects in the brain and promotes disease progression by inducing changes in synaptic functions, behavioral deficits and promoting neuronal degeneration [32-34]. We were able to show that partial MyD88 gene deletion caused significant increases in soluble $A \beta$ species in extracellular, intracellular and membrane-associated enriched protein pools. Nevertheless, we cannot rule out the possibility that the membrane-associated enriched proteins can also contain insoluble $A \beta$, because of the $3 \%$ SDS concentration used in the buffer. Although sAPP $\alpha$ fragment is known to be a neurotrophic factor when it is secreted in the extracellular space $[35,36], \mathrm{A} \beta$ has been shown to promote microtubule transport impairments in neurons and subsequently sequester SAPP $\alpha$ inside the cell and prevent its secretion [37]. Accordingly, sAPP $\alpha$ fragment levels were higher in intracellular proteins fractions of $\mathrm{APP}_{\text {swe }} /$ $\mathrm{PS} 1-\mathrm{MyD} 8^{+/}$mice while there was no significant difference in extracellular-enriched proteins level. 
It is tempting to propose that senile plaques may serve as an inert reservoir of $A \beta$, thus protecting neurons from soluble oligomeric forms of $\mathrm{A} \beta$ [38]. These data regarding the plaque load are in agreement with our previous study in the $\mathrm{APP}_{\text {swe }} / \mathrm{PS} 1-\mathrm{TLR}^{-/-}$mice that had less $\mathrm{A} \beta$ plaques than their control $\mathrm{APP}_{\text {swe }} / \mathrm{PS} 1$ littermates [21]. As in $\mathrm{APP}_{\text {swe }} / \mathrm{PS} 1-\mathrm{MyD} 8^{+/-}$mice, memory capacities did not correlate with plaque load in the brain of $\mathrm{APP}_{\text {swe }} / \mathrm{PS} 1-\mathrm{TLR}^{-/-}$mice. TLRs and MyD88 signaling may have a more direct role on the clearance of soluble oligomeric $A \beta$.

Analyze of blood monocyte subsets revealed changes in $\mathrm{APP}_{\text {swe }} / \mathrm{PS} 1$ mice in a context of partial MyD88 deficiency. These mice exhibited significant relative decrease in $\mathrm{Gr}^{+}$and increase in $\mathrm{Gr}^{-}$monocytes. Globally, there was a $30 \%$ reduction in the ratio of $\mathrm{Gr}^{+} / \mathrm{Gr} 1^{-}$monocytes in blood of $\mathrm{APP}_{\text {swe }} / \mathrm{PS} 1-\mathrm{MyD} 88^{+/-}$compared to $\mathrm{APP}_{\text {swe }} / \mathrm{PS} 1$ mice. As explained earlier, inflammatory monocytes $\left(\mathrm{CX}_{3} \mathrm{CR}_{1}{ }^{\mathrm{Lo}} \mathrm{CCR} 2^{+} \mathrm{Gr} 1^{+}\right)$and resident monocytes $\left(\mathrm{CX}_{3} \mathrm{CR}_{1}{ }^{\mathrm{Hi}} \mathrm{CCR} 2^{-} \mathrm{Gr}^{-}\right)$seem to play opposite roles. Inflammatory monocytes are recruited quickly to inflammatory sites and differentiate into tissue specific macrophages and dendritic cells, whereas resident monocytes infiltrate tissues in an inflammation-independent fashion [24]. This process has been described in different tissues including brain in mouse models of multiple sclerosis [39] and axonal injury [40]. Moreover, inflammatory monocytes have also been shown to be the main precursors for microglial cells under inflammatory conditions of the CNS $[41,42]$. MCP-1 (CCL2) is a major chemiokine involved in the recruitment of monocytes in $\mathrm{AD}$ patients $[43,44]$ and in mouse models of this pathology $[45,46]$. Since interaction between MCP-1 and its binding CCR2 receptor stimulates the mobilization of bone marrow-derived inflammatory monocytes [47], a decrease production of this chemokine may be the mechanism underlying the $30 \%$ reduction in the ratio of $\mathrm{Gr}^{+} / \mathrm{Gr}^{-}$monocytes in blood of $\mathrm{APP}_{\text {swe }} / \mathrm{PS} 1-\mathrm{MyD} 88$ $+/$. In this regard, MyD88 signaling is essential for the transcriptional activation of MCP-1 in response to bacterial ligands [15,48], brain injury [40] and endogenously produced toxic proteins [14]. Moreover, MyD88deficient mice have impaired monopoiesis during bacterial infection resulting in significant reduction in blood, splenic and bone marrow progenitors of inflammatory monocytes [49]. This suggests an important role for MyD88-mediated monocyte homeostasis under inflammatory conditions.

On the other hand, it seems that inflammatory $\mathrm{CX}_{3} \mathrm{CR}_{1}{ }^{\mathrm{Lo}} \mathrm{CCR} 2{ }^{+} \mathrm{Gr}^{+}$monocytes differentiate preferentially in $\mathrm{M} 1$-like macrophages while resident $\mathrm{CX}_{3} \mathrm{CR}_{1}{ }^{\mathrm{Hi}} \mathrm{CCR}^{-} \mathrm{Gr}^{-}$monocytes are likely to become M2-like macrophages [50,51]. M1 macrophages are known to have high phagocytic, proteolytic and inflammatory functions while M2 is suggested to be an anti-inflammatory subset, which is known to promote functions such as tissue remodeling, angiogenesis and matrix deposition [52]. M1-like macrophages would therefore be more efficient to clear $A \beta$ from the brain in a context of chronic inflammation induced by accumulation of cerebral $A \beta$. Taking that into consideration, a decreased $\mathrm{Gr}^{+} / \mathrm{Gr}^{-}$ratio in the pool of available monocytes of $\mathrm{APP}_{\text {swe }} / \mathrm{PS} 1-\mathrm{MyD} 88^{+/-}$mice may be associated with less M1-like macrophages and more M2-like cells and explain the higher levels of soluble $A \beta$ in brain of $\mathrm{APP}_{\text {swe }} / \mathrm{PS} 1-\mathrm{MyD} 88^{+/-}$mice. However, such a possible mechanism has to be fully investigated.

Low IL-1 $\beta$ mRNA levels in the brain of $\mathrm{APP}_{\text {swe }} / \mathrm{PS} 1$ -

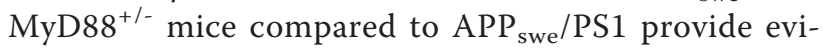
dence that MyD88 is a critical molecule for the regulation of such inflammatory pathway in response to $A \beta$ accumulation. This cytokine is crucial to orchestrate the inflammatory response by microglia [53] and a sustained production of IL-1 $\beta$ was reported to be beneficial by reducing $\mathrm{A} \beta$ pathology in a mouse model of $\mathrm{AD}$ [54]. We consequently believe that the innate immune response by microglia is compromised in a context of MyD88 deficiency, which may prevent their adequate activation to fight against and clear $\mathrm{A} \beta$ peptides. These data converge into a primary role of MyD88-signaling pathway to act as a natural protective mechanism in presence of toxic $A \beta$.

In summary, we show here that MyD88 plays a significant role in the evolution of AD. Partial MyD88 deficiency worsens cognitive deficit in $\mathrm{APP}_{\text {swe }} / \mathrm{PS} 1$ mice, as well as increases brain soluble oligomeric A $\beta$. Moreover, $\mathrm{APP}_{\text {swe }} / \mathrm{PS} 1$ mice deficient in MyD88 have reduced IL$1 \beta$ gene expression and altered blood monocyte homeostasis leading to a decrease in the inflammatory population. Altogether, these results clearly demonstrate the crucial role of functional MyD88 signaling and support the importance of TLRs to prevent or delay AD pathology.

\section{Acknowledgements}

The Canadian Institutes in Health Research (ClHR) and Neuroscience Canada (Brain Repair Program) supported this research. SR holds a Canadian

Research Chair in Neuroimmunology. We acknowledge the contribution of Dr. Mohammed Filali, Martine Lessard and Marie-Michèle Plante for technical helps. MyD88-deficient (MyD88 ${ }^{-1}$ ) mice were generously provided by Dr S Akira (Department of Host Defense, Research Institute for Microbial Diseases, Osaka University, Osaka, Japan).

\section{Authors' contributions}

JPM carried out western blots, FACS experiments and Q-PCR. KR carried out stereology analysis, behavioral tests and Q-PCR. JPM and KR performed statistical analysis and drafted the manuscript. SR conceived of the study, participated in its design and coordination and helped to draft the manuscript. All authors read and approved the final manuscript.

\section{Competing interests}

The authors declare that they have no competing interests. 
Received: 30 September 2010 Accepted: 14 January 2011

Published: 14 January 2011

\section{References}

1. Hardy JA, Higgins GA: Alzheimer's disease: the amyloid cascade hypothesis. Science 1992, 256:184-185.

2. McLean CA, Cherny RA, Fraser FW, Fuller SJ, Smith MJ, Beyreuther K, Bush Al, Masters CL: Soluble pool of Abeta amyloid as a determinant of severity of neurodegeneration in Alzheimer's disease. Ann Neurol 1999, 46:860-866.

3. Hanisch UK, Kettenmann H: Microglia: active sensor and versatile effector cells in the normal and pathologic brain. Nat Neurosci 2007, 10:1387-1394

4. Rivest S: Regulation of innate immune responses in the brain. Nat Rev Immunol 2009, 9:429-439.

5. Ransohoff RM, Perry VH: Microglial physiology: unique stimuli, specialized responses. Annu Rev Immunol 2009, 27:119-145.

6. Heneka MT, O'Banion MK: Inflammatory processes in Alzheimer's disease. J Neuroimmunol 2007, 184:69-91.

7. Kawai T, Akira S: The role of pattern-recognition receptors in innate immunity: update on Toll-like receptors. Nat Immunol 2010, 11:373-384.

8. Akira S, Uematsu S, Takeuchi O: Pathogen recognition and innate immunity. Cell 2006, 124:783-801.

9. Frank S, Copanaki E, Burbach GJ, Muller UC, Deller T: Differential regulation of toll-like receptor mRNAs in amyloid plaque-associated brain tissue of aged APP23 transgenic mice. Neurosci Lett 2009, 453:41-44.

10. Scholtzova H, Kascsak RJ, Bates KA, Boutajangout A, Kerr DJ, Meeker HC, Mehta PD, Spinner DS, Wisniewski T: Induction of toll-like receptor 9 signaling as a method for ameliorating Alzheimer's disease-related pathology. J Neurosci 2009, 29:1846-1854.

11. Tahara K, Kim HD, Jin JJ, Maxwell JA, Li L, Fukuchi K: Role of toll-like receptor signalling in Abeta uptake and clearance. Brain 2006, 129:3006-3019.

12. Balistreri CR, Grimaldi MP, Chiappelli M, Licastro F, Castiglia L, Listi F, Vasto S, Lio D, Caruso C, Candore G: Association between the polymorphisms of TLR4 and CD14 genes and Alzheimer's disease. Curr Pharm Des 2008, 14:2672-2677.

13. Reed-Geaghan EG, Savage JC, Hise AG, Landreth GE: CD14 and toll-like receptors 2 and 4 are required for fibrillar A\{beta\}-stimulated microglial activation. J Neurosci 2009, 29:11982-11992.

14. Kang J, Rivest S: MyD88-deficient bone marrow cells accelerate onset and reduce survival in a mouse model of amyotrophic lateral sclerosis. J Cell Biol 2007, 179:1219-1230.

15. Naert G, Laflamme N, Rivest S: Toll-like receptor 2-independent and MyD88-dependent gene expression in the mouse brain. J Innate Immun 2009, 1:480-493.

16. Simard AR, Soulet D, Gowing G, Julien JP, Rivest $\mathrm{S}$ : Bone marrow-derived microglia play a critical role in restricting senile plaque formation in Alzheimer's disease. Neuron 2006, 49:489-502

17. Lesne S, Koh MT, Kotilinek L, Kayed R, Glabe CG, Yang A, Gallagher M, Ashe $\mathrm{KH}$ : A specific amyloid-beta protein assembly in the brain impairs memory. Nature 2006, 440:352-357.

18. Luu-The V, Paquet N, Calvo E, Cumps J: Improved real-time RT-PCR method for high-throughput measurements using second derivative calculation and double correction. BioTechniques 2005, 38:287-293.

19. Rogers DC, Fisher EM, Brown SD, Peters J, Hunter AJ, Martin JE: Behavioral and functional analysis of mouse phenotype: SHIRPA, a proposed protocol for comprehensive phenotype assessment. Mamm Genome 1997, 8:711-713.

20. Jana M, Palencia CA, Pahan K: Fibrillar amyloid-beta peptides activate microglia via TLR2: implications for Alzheimer's disease. J Immunol 2008, 181:7254-7262.

21. Richard KL, Filali M, Prefontaine P, Rivest S: Toll-like receptor 2 acts as a natural innate immune receptor to clear amyloid beta 1-42 and delay the cognitive decline in a mouse model of Alzheimer's disease. $J$ Neurosci 2008, 28:5784-5793.

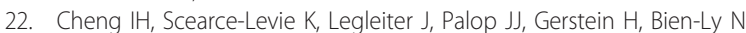
Puolivali J, Lesne S, Ashe KH, Muchowski PJ, Mucke L: Accelerating amyloid-beta fibrillization reduces oligomer levels and functional deficits in Alzheimer disease mouse models. J Biol Chem 2007, 282:23818-23828.
23. Kayed R, Head E, Thompson JL, McIntire TM, Milton SC, Cotman CW, Glabe CG: Common structure of soluble amyloid oligomers implies common mechanism of pathogenesis. Science 2003, 300:486-489.

24. Geissmann F, Jung S, Littman DR: Blood monocytes consist of two principal subsets with distinct migratory properties. Immunity 2003, 19:71-82.

25. Fassbender K, Walter S, Kuhl S, Landmann R, Ishii K, Bertsch T, Stalder AK, Muehlhauser F, Liu Y, Ulmer AJ, et al: The LPS receptor (CD14) links innate immunity with Alzheimer's disease. FASEB J 2004, 18:203-205.

26. Letiembre M, Liu Y, Walter S, Hao W, Pfander T, Wrede A, SchulzSchaeffer W, Fassbender K: Screening of innate immune receptors in neurodegenerative diseases: a similar pattern. Neurobiol Aging 2009, 30:759-768.

27. Liu Y, Walter S, Stagi M, Cherny D, Letiembre M, Schulz-Schaeffer W Heine H, Penke B, Neumann H, Fassbender K: LPS receptor (CD14): a receptor for phagocytosis of Alzheimer's amyloid peptide. Brain 2005, 128:1778-1789.

28. Walter S, Letiembre M, Liu Y, Heine H, Penke B, Hao W, Bode B, Manietta N, Walter J, Schulz-Schuffer W, Fassbender K: Role of the toll-like receptor 4 in neuroinflammation in Alzheimer's disease. Cell Physiol Biochem 2007, 20:947-956.

29. Chen K, Iribarren P, Hu J, Chen J, Gong W, Cho EH, Lockett S, Dunlop NM Wang JM: Activation of Toll-like receptor 2 on microglia promotes cell uptake of Alzheimer disease-associated amyloid beta peptide. J Biol Chem 2006, 281:3651-3659.

30. Iribarren P, Chen K, Hu J, Gong W, Cho EH, Lockett S, Uranchimeg B, Wang JM: CpG-containing oligodeoxynucleotide promotes microglial cell uptake of amyloid beta 1-42 peptide by up-regulating the expression of the G-protein- coupled receptor mFPR2. Faseb J 2005, 19:2032-2034.

31. Kakimura J, Kitamura Y, Takata K, Umeki M, Suzuki S, Shibagaki K, Taniguchi T, Nomura Y, Gebicke-Haerter PJ, Smith MA, et al: Microglial activation and amyloid-beta clearance induced by exogenous heatshock proteins. FASEB J 2002, 16:601-603.

32. Kim HJ, Chae SC, Lee DK, Chromy B, Lee SC, Park YC, Klein WL, Krafft GA, Hong ST: Selective neuronal degeneration induced by soluble oligomeric amyloid beta protein. FASEB J 2003, 17:118-120.

33. Lacor PN, Buniel MC, Furlow PW, Clemente AS, Velasco PT, Wood M, Viola KL, Klein WL: Abeta oligomer-induced aberrations in synapse composition, shape, and density provide a molecular basis for loss of connectivity in Alzheimer's disease. J Neurosci 2007, 27:796-807.

34. Lue LF, Kuo YM, Roher AE, Brachova L, Shen Y, Sue L, Beach T, Kurth JH, Rydel RE, Rogers J: Soluble amyloid beta peptide concentration as a predictor of synaptic change in Alzheimer's disease. Am J Pathol 1999, 155:853-862.

35. Meziane H, Dodart JC, Mathis C, Little S, Clemens J, Paul SM, Ungerer A: Memory-enhancing effects of secreted forms of the beta-amyloid precursor protein in normal and amnestic mice. Proc Natl Acad Sci USA 1998, 95:12683-12688.

36. Taylor CJ, Ireland DR, Ballagh I, Bourne K, Marechal NM, Turner PR, Bilkey DK, Tate WP, Abraham WC: Endogenous secreted amyloid precursor protein-alpha regulates hippocampal NMDA receptor function, long-term potentiation and spatial memory. Neurobiol Dis 2008, 31:250-260.

37. Henriques AG, Vieira SI, da Cruz ESEF, da Cruz ESOA: Abeta promotes Alzheimer's disease-like cytoskeleton abnormalities with consequences to APP processing in neurons. J Neurochem 2010, 113:761-771.

38. Xue WF, Hellewell AL, Gosal WS, Homans SW, Hewitt EW, Radford SE: Fibril fragmentation enhances amyloid cytotoxicity. J Biol Chem 2009, 284:34272-34282.

39. Izikson L, Klein RS, Charo IF, Weiner HL, Luster AD: Resistance to experimental autoimmune encephalomyelitis in mice lacking the CC chemokine receptor (CCR)2. J Exp Med 2000, 192:1075-1080.

40. Babcock AA, Kuziel WA, Rivest $\mathrm{S}$, Owens T: Chemokine expression by glial cells directs leukocytes to sites of axonal injury in the CNS. J Neurosci 2003, 23:7922-7930.

41. Getts DR, Terry RL, Getts MT, Muller M, Rana S, Shrestha B, Radford J, Van Rooijen N, Campbell IL, King NJ: Ly6c+ "inflammatory monocytes" are microglial precursors recruited in a pathogenic manner in West Nile virus encephalitis. J Exp Med 2008, 205:2319-2337. 
42. Mildner A, Schmidt $H$, Nitsche M, Merkler D, Hanisch UK, Mack M, Heikenwalder M, Bruck W, Priller J, Prinz M: Microglia in the adult brain arise from Ly-6ChiCCR2+ monocytes only under defined host conditions. Nat Neurosci 2007, 10:1544-1553.

43. Grammas P, Ovase R: Inflammatory factors are elevated in brain microvessels in Alzheimer's disease. Neurobiol Aging 2001, 22:837-842.

44. Sokolova A, Hill MD, Rahimi F, Warden LA, Halliday GM, Shepherd CE: Monocyte chemoattractant protein-1 plays a dominant role in the chronic inflammation observed in Alzheimer's disease. Brain Pathol 2009, 19:392-398.

45. El Khoury J, Toft M, Hickman SE, Means TK, Terada K, Geula C, Luster AD: Ccr2 deficiency impairs microglial accumulation and accelerates progression of Alzheimer-like disease. Nat Med 2007, 13:432-438.

46. Ishizuka K, Kimura T, Igata-yi R, Katsuragi S, Takamatsu J, Miyakawa T: Identification of monocyte chemoattractant protein-1 in senile plaques and reactive microglia of Alzheimer's disease. Psychiatry Clin Neurosci 1997, 51:135-138.

47. Serbina NV, Pamer EG: Monocyte emigration from bone marrow during bacterial infection requires signals mediated by chemokine receptor CCR2. Nat Immunol 2006, 7:311-317.

48. Jia T, Leiner I, Dorothee G, Brandl K, Pamer EG: MyD88 and Type I interferon receptor-mediated chemokine induction and monocyte recruitment during Listeria monocytogenes infection. J Immunol 2009, 183:1271-1278.

49. Delano MJ, Scumpia PO, Weinstein JS, Coco D, Nagaraj S, Kelly-Scumpia KM O'Malley KA, Wynn JL, Antonenko S, Al-Quran SZ, Swan R, Chung CS, Atkinson MA, Ramphal R, Gabrilovich DI, Reeves WH, Ayala A, Phillips J, Laface D, Heyworth PG, Clare-Salzler M, Moldawer LL: MyD88-dependent expansion of an immature GR-1(+)CD11b(+) population induces $\mathrm{T}$ cell suppression and Th2 polarization in sepsis. J Exp Med 2007, 204:1463-74.

50. Arnold L, Henry A, Poron F, Baba-Amer Y, van Rooijen N, Plonquet A, Gherardi RK, Chazaud B: Inflammatory monocytes recruited after skeletal muscle injury switch into antiinflammatory macrophages to support myogenesis. J Exp Med 2007, 204:1057-1069.

51. Nahrendorf M, Swirski FK, Aikawa E, Stangenberg L, Wurdinger T, Figueiredo JL, Libby P, Weissleder R, Pittet MJ: The healing myocardium sequentially mobilizes two monocyte subsets with divergent and complementary functions. J Exp Med 2007, 204:3037-3047.

52. Mantovani A, Sica A, Sozzani S, Allavena P, Vecchi A, Locati M: The chemokine system in diverse forms of macrophage activation and polarization. Trends Immunol 2004, 25:677-686.

53. Gosselin D, Rivest S: Role of IL-1 and TNF in the brain: twenty years of progress on a Dr. Jekyl/Mr. Hyde duality of the innate immune system. Brain Behav Immun 2007, 21:281-9.

54. Shaftel SS, Kyrkanides S, Olschowka JA, Miller JN, Johnson RE, O'Banion MK: Sustained hippocampal IL-1 beta overexpression mediates chronic neuroinflammation and ameliorates Alzheimer plaque pathology. I Clin Invest 2007, 117:1595-604.

doi:10.1186/1750-1326-6-5

Cite this article as: Michaud et al:: MyD88-adaptor protein acts as a preventive mechanism for memory deficits in a mouse model of Alzheimer's disease. Molecular Neurodegeneration 2011 6:5.

\section{Submit your next manuscript to BioMed Central and take full advantage of:}

- Convenient online submission

- Thorough peer review

- No space constraints or color figure charges

- Immediate publication on acceptance

- Inclusion in PubMed, CAS, Scopus and Google Scholar

- Research which is freely available for redistribution

Submit your manuscript at www.biomedcentral.com/submit 